\title{
Sürücülerin Algısal Motor ve Güvenlik Becerilerinin İșitsel ve Görsel İkincil Görev Sırasında Sergilenen Şerit Koruma Performansındaki Rolü
}

\author{
Seda Özbozdağlı ${ }^{*}$, Mine Mısırlısoy ${ }^{1}$, Türker Özkan¹, Nart Bedin Atalay² \\ ${ }^{1}$ Psikoloji Bölümü, Orta Doğu Teknik Üniversitesi, Ankara Türkiye. \\ ${ }^{2}$ Psikoloji Bölümü, TOBB Ekonomi ve Teknoloji Üniversitesi, Ankara Türkiye.
}

$\ddot{O} \mathbf{z}$

Mevcut çalışmanın amacı, sürücülerin algısal motor ve güvenlik becerileri hakkındaki değerlendirmelerinin işitsel ve görsel ikincil görevler sırasında sergilenen şerit pozisyonundaki değişkenliği yordama güçlerini araştırmaktır. Araç simülatörünün kullanıldığı deneylere toplamda 66 sürücü katılımda bulunmuştur. Görsel ve işitsel ikincil görev gruplarına eşit şekilde atanan katılımcılardan Sürücülük Becerisi Ölçeğini doldurmaları istenmiştir. Çoklu doğrusal regresyon analizlerinden elde edilen bulgulara göre, işitsel ikincil görev sürüşe eşlik ettiğinde, algısal motor ve güvenlik becerilerinin şeritten sapma miktarını yordamadaki katkıları anlamlı değildir. İşitsel görev grubundaki katılımcılar sadece sürüş ile ilgilendiklerinde, algısal motor becerilerin şerit pozisyonundaki değişkenlik ile negatif yönde ilişkili olduğu bulunmuştur. İkincil görevin görsel olduğu durumda ve aynı grubun sadece sürüşe odaklandığı durumda algısal motor beceriler ile şerit pozisyonundaki değişkenlik arasında negatif bir ilişki saptanmıştır. Hem işitsel hem görsel ikincil görev gruplarındaki tüm deney koşullarında, güvenlik becerileri ile şerit pozisyonundaki değişkenlik arasında anlamlı bir ilişki tespit edilememiştir. İlgili alanyazın temel alınarak çalışmadan elde edilen bulgular tartışılmıştır.

Anahtar Kelimeler: algısal motor beceriler, güvenlik becerileri, araç kullanma, işitsel ikincil görev, görsel ikincil görev

\section{The Role of Drivers' Perceptual Motor and Safety Skills in Lane Maintenance During Auditory and Visual Secondary Tasks}

\begin{abstract}
The objective of this work was to investigate the predictive power of drivers' assessments about their perceptual motor and safety skills for the variability in lane position during auditory and visual secondary tasks. A total of 66 drivers participated in the experiments and drove a simulated vehicle. Participants equally assigned to auditory and visual secondary task conditions were asked to fill out the Driver Skill Inventory. Results of the multiple linear regression analyses showed that when the auditory secondary task accompanied driving, perceptual motor and safety skills did not significantly predict the variability in lane position. When the drivers who were in the auditory task group only engaged in driving, perceptual motor skills and variability in lane position were found to be negatively related. There was also a negative relationship between perceptual motor skills and variability in lane position in both visual secondary task and driving-only conditions. In none of the experimental conditions of auditory and visual secondary task groups, a significant relationship between safety skills and variability in lane position was found. Findings were discussed based on the relevant literature.
\end{abstract}

Keywords: perceptual motor skills, safety skills, driving, auditory secondary task, visual secondary task

\footnotetext{
'Iletişim / Contact: Seda Özbozdağll, Psikoloji Bölümü, Orta Doğu Teknik Üniversitesi, Ankara Türkiye. E-Posta / Email: seda.ozbozdagli@metu.edu.tr Gönderildiği tarihi / Date submitted: 30.04.2018, Kabul edildiği tarih / Date accepted: 19.10.2018

Alıntı / Citation: Özbozdağlı, S., Mısırlısoy, M., Özkan, T. ve Atalay, N. B. (2018). Sürücülerin Algısal Motor ve Güvenlik Becerilerinin İşitsel ve Görsel İkincil Görev Sırasında Sergilenen Şerit Koruma Performansındaki Rolü. Trafik ve Ulaşım Araştırmaları Dergisi, 1(2), 48-61.
} 


\section{Sürücülerin Algısal Motor ve Güvenlik Becerilerinin İşitsel ve Görsel İkincil Görev Sırasında Sergilenen Şerit Koruma Performansındaki Rolü}

Trafik kazalarının temelinde yatan önemli etmenlerden biri dikkatsiz araç kullanımıdır (National Center for Statistics and Analysis [NCSA], 2017). Direksiyon başındayken yapılan ve dikkatin yoldan ayrılmasına sebep olan tüm aktiviteler dikkat dağıtıcı sayılmaktadır. Sürücüler seyir halinde farklı duyuların faal olmasını gerektiren dikkat dağıtıcı görevlerle meşgul olabilmektedirler. Hareket eden bir araçta telefonla konuşmak, yolcularla sohbet etmek veya radyo dinlemek gibi işitme duyusunu çalıştıran aktiviteler sürücünün dikkati yoldan alan işitsel ikincil görevler arasında yer almaktadır. Navigasyon cihazını takip etmek, kısa mesaj okumak ve yazmak, sosyal medya hesaplarına göz atmak ya da yoldaki reklam tabelaları gibi trafik ile doğrudan ilgisi olmayan uyarıcılara bakmak ise dikkat dağınıklığına yol açabilen görsel ikincil görevler arasında bulunmaktadır.

Türkiye İstatistik Kurumu'nun paylaştığı karayolu trafik kaza istatistiklerine göre 2016 senesinde Türkiye'de meydana gelen 1.182.491 trafik kazasından 185.128'i ölümlü yaralanmalı kazalardır. Bu kazaların sonucunda 7.300 kişi hayatını kaybetmiş ve 303.812 kişi yaralanmıştır. Gerçekleşen ölümlü yaralanmalı kazaların nedenleri incelendiğinde kusurların \%89,6'sının sürücülere ait olduğu görülmektedir (Türkiye İstatistik Kurumu [TÜİK], 2017). Amerika Birleşik Devletleri'nin tüm eyaletlerden toplanan trafik kaza verilerine dayanarak hazırlanan bir raporda ise 2015 yılında meydana gelen ölümlü kazaların \%10'unun sebebinin dikkati dağılmış sürücüler olduğu belirtilmiştir. Dikkatsiz araç kullanımından kaynaklı kazalarda 3.477 kişi can vermiş, 391.000 kişi de yaralanmıştır (NCSA, 2017). Trafik kazalarında insan faktörünün öne çıkması mevcut çalışmanın odağına sürücülerin dikkatlerini dağıtan ikincil görevlerin ve buna ilaveten sürücülerin sürüş ve güvenli araç kullanma becerileri hakkındaki öz değerlendirmelerinin alınmasında etken olmuştur. Zira araç kullanma becerilerine fazlaca güvenen sürücüler iki görevi aynı yapmanın üstesinden gelebileceklerini, yeteneklerinin ikinci bir görevle meşgul olmanın yarattığ 1 kaza riskini telafi edeceğini düşünebilirler.

\section{1. İşitsel İkincil Görevin Sürüşe Etkileri}

Varış noktasına güvenli bir şekilde ulaşabilmek için sürücünün daimî dikkati gereklidir. Ancak sürücüler potansiyel riskler hakkında bilgi sahibi olsalar da direksiyondayken başka bir aktivite ile ilgilenebilmektedirler. Örneğin, yapılan bir ankette katılımcıların yaklaşık olarak yarısı $(\% 48)$ araç kullanırken gelen aramalara cevap verdiğini, \%24'ü ise arama yaptığını kabul etmiştir. Aranan sürücülerin \%58'i aracı yol kenarına çekmemiş ve telefonda görüşme yaparken araba sürmeye devam etmişlerdir (Schroeder, Meyers ve Kostyniuk, 2013).

Direksiyon başında telefonda konuşmak sürüşü pek çok açıdan kötü etkilemektedir. Telefonda görüşme yapmak kaza sayısının artmasına yol açmıştır ve konuşma esnasında sürücüler daha yavaş tepkiler vermiş, daha çok sürüş hatası yapmış, fren sonrası eski hızlarına daha geç ulaşmışlardır. (Drews, Pasupathi ve Strayer, 2008; Haque ve Washington, 2014; Strayer ve Drews, 2004; Strayer, Drews ve Crouch, 2006). Telefon konuşması yaparken trafikte oluşan riskli durumlara geç tepki verildiği yine bir derleme çalışmasında gösterilmiştir. (Caird, Willness, Steel ve Scialfa, 2008).

Telefonla konuşmanın sürüş üzerindeki bu olumsuz etkilerinin aksine şerit koruma performansını iyileştirdiğini gösteren çalışmalar mevcuttur. Beede ve Kass (2006) şerit pozisyonundaki değişkenliğin ellerin serbest olduğu cep telefonu görüşmeleri sırasında azaldığını tespit etmiştir. Deneyimli sürücülerin katıldığı işitsel ikincil görev kullanılan bir çalışmada ise, ikincil görev koşulunda şerit koruma performansının arttığı saptanmıştır (Medeiros-Ward, Cooper ve Strayer, 2014). Bahsi geçen araştırmada kullanılan görev Mehler,

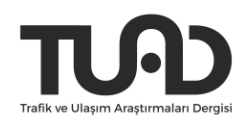


Reimer ve Dusek (2011) tarafından geliştirilen n-geri görevidir. Bu görevde, uyarıcılar dinlenerek verilen yönerge gereğince belirli aralıklarla cevap verildiği için eller serbest şekilde telefon görüşmesi yapmaya benzetilebilir.

Telefonda konuşmak hem karşı tarafı dinlemeyi hem de sohbetin gidişatına uygun olarak karşılık vermeyi gerektirir. Kubose ve diğerleri (2006) konuşma üretmenin ve konuşulanı anlamanın sürüş performansı üzerindeki etkilerini araştırmıştır. Sadece araç kullanmaya oranla, konuşmak şerit pozisyonunu korumayı iyileştirirken, konuşulanı kavramak anlamlı düzeyde bir değişikliğe yol açmamıştır. Bu doğrultuda, alanyazındaki şerit koruma ile ilgili bulguların farklılıkları verilen görevdeki dinleme ve konuşmanın oranlarına bağlı olabilir.

\subsection{Görsel İkincil Görevin Sürüşe Etkileri}

Sürücülerin olası risklere karşı daima tetikte olmaları ve gözlerini yoldan ayırmamaları gerekir. Fakat 2012 yılında yapılan bir ankete katılan sürücülerin \%14'ü direksiyon başındayken kısa mesaj ya da e-posta okuduğunu, \%10'u ise araç kullanırken zaman zaman kısa mesaj ve e-posta gönderdiğini belirtmiştir (Schroeder ve ark., 2013). İşitsel ikincil görevlere nazaran telefondan mesaj okumak veya navigasyon cihazından rotayı incelemek gibi görsel görevler sürücülerin hem dikkatlerini hem de bakışlarını yoldan ayıracağı için daha yüksek oranda risk arz edebilir.

Dikkatli bir sürücü trafiğin taleplerini karşılamak ve yeterli bir performans sergilemek için çevreden yeteri miktarda bilgi toplar. İkincil bir görev ile meşgul olmayan, yalnızca aracını süren bir kişi de eğer toplanan bilgi yetersiz ise dikkatsiz sayılabilir. Bunun yanı sıra, sürücünün deneyim düzeyine ve trafiğin durumuna bağlı olarak ek bilişsel kapasite mevcut ise sürücüler sürüş dışı şeylere dikkatlerini verebilirler (Kircher ve Ahlstrom, 2017). Sürücüler ikincil bir görevle ilgilenecekleri zaman kapasitelerinden pay ayırmayı da seçebilirler. Örneğin, Metz, Schoch, Just ve Kuhn (2014) tarafından yürütülen 3 aylık bir süreyi kapsayan doğal gözlem çalışmasında görülmüştür ki navigasyon cihazıyla ilgilendikleri esnada sürücüler hızlarını yavaşlatmış, daha fazla emniyet payı bırakmış ve daha güvenli olduğunu düşündükleri yol durumlarında cihaza vakit ayırmışlardır. Sürüş şartları zorlaştığında ise ikincil bir görev yapmayı ertelemiş ya da hiç yapmamayı tercih etmişlerdir (Schömig, Metz ve Krüger, 2011). İkincil görevle ilgilenirken sürüşlerini adapte etmeleri hem dikkati yoldan ayırmanın riskinin farkında olduklarına hem de bilişsel kapasitelerinin sınırlı olduğunu sezinlediklerine dair bir gösterge olabilir. Mevcut çalışmada navigasyon cihazını izleme davranışı ile benzeşen bir görsel ikincil görev kullanılmıştır.

Güzergâh belirlemek gibi sürüş ile ilgili bir amaca hizmet etmeyen fakat yine de görsel dikkat gerektiren diğer aktivitelerin, sürücü davranışları üzerindeki etkilerinin incelendiği çalışmalar da gözleri yoldan ayırmanın neticelerini göstermektedir. Thapa, Codjoe, Ishak ve McCarter (2015) direksiyon başındayken cep telefonu ile görüşme yapmanın şerit koruma üzerinde anlamlı bir etkisini gözlemlememiştir fakat kısa mesaj göndermenin anlamlı olumsuz etkisini saptamıştır. Mesaj metnini manuel olarak veya sesli komutla girmenin şerit pozisyonundaki değişkenliği arttırdığı bulunmuştur (He, Choi, McCarley, Chaparro ve Wang, 2015).

İşitsel görevlere kıyasla görsel görevlerin sürüşte daha yüksek oranda performans kaybına yol açtığ1 görülmüştür (Liang ve Lee, 2010). Örneğin, Parkes ve Coleman (1990) tarafından yürütülen bir çalışmada, sürücülerin yönergeleri dinlemeleri, aynı talimatların olduğu metni okumalarına oranla daha iyi bir sürüş performansı göstermeleriyle sonuçlanmıştır. Treisman ve Davies (1973) aynı anda sürdürülen iki görev görselse, birinin görsel diğerinin işitsel olduğu duruma kıyasla performansın daha kötü etkileneceğini öne sürmüştür. Şerit koruma performansı da işitsel görev zorlaştığında iyileşirken görsel görev zorlaştığında kötüleşmiştir (Jamson ve Merat, 2005). Benzer şekilde, Engström, Johansson ve Östlund (2005) tarafından yapılan bir çalışmada, sürüşün işitsel ve görsel ikincil görevlerden farklı şekilde etkilendiği

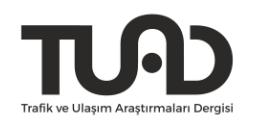


savını destekleyen bulgular elde edilmiştir. Direksiyon başında görsel görevle meşgul olunduğunda şeritten daha çok sapılmış ve de daha düşük hızda gidilmiştir. Bununla birlikte, işitsel görev esnasında hızda anlamlı bir değişiklik kaydedilmemiştir. Daha da önemlisi, şerit pozisyonundaki değişkenlik azalmıştır. Engström ve ark. (2005), mevcut dikkat kapasitesinin ikincil bir görev ile ilgilenirken azalmasının akabinde yolun her zamanki şekilde taranmasının zorlaşacağını, dolayısıyla şerit pozisyonundaki değişkenliğin azabileceğini ileri sürmüştür. Yazarlara göre, dikkati yol ve işitsel görev arasında bölünen sürücü, periferik görüşünden feragat ederek dikkatini yolun merkezine verir. Bu da şerit koruma için daha çok veri alınmasını sağlar ve sonuç olarak, sapma miktarını azaltır (Engström ve ark., 2005). İşitsel görev sırasında yolun merkezine odaklanılması şerit pozisyonundaki değişkenliğin azalmasını açıklayabilir. Fakat ikincil görevin görsel olduğu durumda bu etki tersi yöne dönebilir.

Geçmiş çalışmalar şerit koruma performansının işitsel ve görsel ikincil görevlerden farklı şekilde etkilendiğini işaret etmektedir. İşitsel bir göreve dikkatlerini veren deneyimli sürücüler şeritten daha az sapmıştır (Medeiros-Ward ve ark., 2014). Tecrübe sahibi sürücüler için şerit korumak otomatikleşmiş bir davranıştır. Bilişsel bir yük yaratan işitsel görev yürütüldüğü esnada araç kullanmanın tüm detaylarına odaklanılamayacağı için şeritten daha az sapılacağı ileri sürülmüştür (Medeiros-Ward ve ark., 2014). Engström ve ark. (2005) ise, sürüşe işitsel görevin eşlik ettiği sırada görülen iyileşmeyi iki görev arasında paylaşılan dikkatin tasarruflu bir şekilde kullanılarak yolun merkezine verilmesine bağlamıştır. Diğer bir yandan, iki tür ikincil görevin karşılaştırıldığı çalışmalarda görülmüştür ki işitsel görev yapılırken iyiye giden şerit koruma performans1, görsel görev yapıldığında kötüye gitmiştir (Engström ve ark., 2005; Jamson ve Merat, 2005). Çünkü, araç kullanmak görsel dikkat gerektirir ve başka bir görsel görev ile eş zamanlı yapıldığında gözler yoldan ayrılacağından dolayı performansta düşme görülebilir (Treisman ve Davies, 1973). Bu bakımdan, mevcut çalışmanın amaçlarından biri, benzer tarzda bilişsel yük yaratan işitsel ve görsel görevler kullanarak, farklı tür ikincil görevlerin şerit koruma performansı üzerindeki etkileri hakkında daha fazla bilgi edinmektir.

\subsection{Sürüş Becerilerinin Öz Değerlendirilmesi}

Trafiği oluşturan unsurlar ve sürücü arasında karş1lıklı bir etkileşim söz konusudur. Sürücü, trafiğin karışık olmadığı, aracı yönetmenin yoğun dikkat gerektirmediğini düşündüğü şartlarda ilave bir görev ile ilgilenmeyi seçebilir. Sürücülük becerilerine güvenen bir kişi ise kalabalık ve karmaşık bir trafik ortamında bile, becerilerinin oluşan herhangi bir riski telafi edeceğini düşünerek ikincil bir görev ile ilgilenebilmektedir. Öte yandan, güvenli araç kullanmaya öncelik veren bir sürücü ise dikkatini yoldan ayırmamayı tercih edebilir. Sonuç olarak, araç sürme eylemini gerçekleştiren kişi olan sürücünün kendi becerileri hakkındaki değerlendirmeleri ve güvenli araç kullanma anlayışı, direksiyon başındayken başka bir görevle ilgilenmeyi tercih edip etmeyeceğini belirleyen faktörler arasında yer alabilir. Bunun yanı sıra, kişinin hangi tür dikkat dağıtıcı görevleri yapmayı kabul edeceği yine sürücülük becerileri hakkındaki öz değerlendirmesine dayanabilir.

Sürücülük becerileri, algısal motor beceriler ve güvenlik becerileri olarak iki tür beceriyi kapsamaktadır. Algısal motor beceriler araç kullanmak için gerekli olan fiziksel ve zihinsel özellikleri içerirken güvenlik becerileri ise sürücülerin kazalardan sakınma, trafik kurallara uyma gibi davranışlarda ne derecede bulunduklarını göstermektedir (Lajunen ve Summala, 1995). Eensoo, Paaver ve Harro (2010) tarafından yapılan bir çalışmada algısal motor becerilerin olduğundan fazla değerlendirilmesinin hız ihlallerinin en güçlü yordayıcılarından biri olduğu görülmüştür. İlaveten, başka bir çalışmada güvenlik becerilerinin kaza ve trafik cezası sayısı ile rapor edilen sürüş hızını yordadığı, algısal motor becerinin ise yalnızca ceza sayısını yordadığ 1 tespit edilmiştir. Algısal motor becerilerine fazlaca güvenen sürücülerin becerilerini olduğundan daha iyi değerlendirmelerine ek olarak araç kullanmaya karşı duygusal

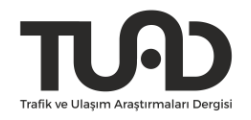


bir tavır takındıkları ve beklentilerini karşılayamayan trafik koşullarında engellenmiş ve öfkeli hissettikleri de elde edilen bulgular arasındadır (Lajunen, Corry, Summala ve Hartley, 1998: Lajunen, Parker ve Stradling, 1998). Algısal motor beceriler ve güvenlik becerilerinin birbirlerine oranının da önemli olduğu çalışmalarda gösterilmiştir. Örneğin, en çok kaza kaydına sahip sürücülerin algısal motor becerilerinin yüksek, güvenlik becerilerinin ise düşük olduğu bulunmuştur. Öte yandan hem algısal motor becerileri hem de güvenli sürüş becerileri yüksek olan kişilerin en az kaza yapanlar oldukları görülmüştür. Dolayısıyla, yüksek algısal motor beceriler güvenlik becerileri ile desteklenmediğinde tehlike arz edebilir (Sümer, Özkan ve Lajunen, 2006). Sümer, Lajunen ve Özkan (2002) tarafindan yürütülen bir çalışmada, araç kullanma becerilerine çokça güvenen, fakat güvenli sürüş becerileri zayıf olan sürücülerin daha fazla sayıda trafik cezası aldıkları ve kaza yaptıkları tespit edilmiştir. Sürücülük becerilerinin hatalı değerlendirilmesi riskin küçümsenmesine, dikkatsiz ve tehlikeli şekilde araç kullanılmasına ve en nihayetinde kazalara yol açabilir.

Yukarıda bahsedilen çalışmalarda işitsel ve görsel ikincil görevlerin şerit pozisyonundaki değişkenlik üzerindeki etkilerinin farklı olabileceği görülmüştür. Fakat algısal motor becerilerin ve güvenlik becerilerinin, sürücü dikkatinin araç kullanma ve işitsel ya da görsel ikincil görev arasında bölündüğü sıradaki şerit koruma performansını ne ölçüde yordadıkları bilinmemektedir. Bu nedenle, mevcut çalışma sürücülerin kendi becerilerine dair algılarının farklı tür ikincil görevler esnasında sergilenen şerit pozisyonundaki değişkenliği yordama güçlerini araştırmak amacıyla yapılmıştır.

\section{Yöntem}

\section{1. Örneklem}

Katılımcılara, Orta Doğu Teknik Üniversitesi Psikoloji Bölümü Katılımcı Kayıt Sistemi ve çeşitli sosyal paylaşım siteleri aracılığıyla ulaşılmıştır. Psikoloji bölümünden bir derse kayıtlı olan öğrenciler, çalışmaya katkıları karşılığında ek puan almışlardır. En az 3 senedir ehliyet sahibi olan ve önceki yıl 3000 km'den fazla yol yapmış 66 sürücü çalışmaya katılmıştır (52 Erkek, 14 Kadın, Ort.yaş=22.74). Katılımcıların tümü işitme duyularında bir problem olmadığını ve görme yetilerinin normal veya normale düzeltilmiş olduğunu belirtmiştir. İşitsel ve görsel ikincil görev gruplarına seçkisiz atama yapılmıştır (İşitsel Grup: 25 Erkek, 8 Kadın, Ort.yaş=22.36; Görsel Grup: 27 Erkek, 6 Kadın, Ort.yaş=23.12).

\subsection{Veri Toplama Araçları}

\subsubsection{Demografik bilgi formu.}

$\mathrm{Bu}$ formda örneklemi tanımlayan faktörlerle ilgili bilgi edinmeye ve araştırma verilerini etkileme olasılığı bulunan bazı değişkenleri saptamaya yönelik maddeler bulunmaktadır. Gerektiğinde kontrol değişkeni olarak değerlendirilebilmeleri amacıyla, sürücülerin deneydeki performanslarına yansıma ihtimali bulunan unsurlar ile ilgili bilgi toplanmıştır. Yaş ve cinsiyet gibi rutin maddelere ek olarak, katılımcıların deneyden önceki gece kaç saat uyudukları, son haftalarda herhangi bir ilaç kullanıp kullanmadıkları ve görme ya da işitme becerilerinde bir sorun olup olmadığ 1 sorulmuştur. Bunlara ilaveten, sürücülerin ehliyet aldıkları sene, toplamda katettikleri mesafe, önceki yıl yaptıkları yol, hız tercihleri, sollama davranışları, kullandıkları araç tipi, son 3 yıl içinde dâhil oldukları kazalar ve aldıkları trafik cezaları ile ilgili bilgiler toplanmıştır.

\subsubsection{Sürücülük becerisi ölçeği.}

Sürücülük Becerisi Ölçeği, sürücülerin kendi sürüş ve güvenli araç kullanma becerilerini değerlendirmeleri için Lajunen ve Summala'nın (1995) geliştirdiği ve Lajunen ve Özkan (2004)

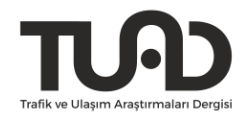


tarafından da dilimize uyarlanan bir ölçüm aracıdır. Beş dereceli likert ölçeği ( $1=$ kesinlikle zayıf, 2=zayıf, $3=$ ne zayıf ne de güçlü, $4=$ =ü̈çlü, 5=kesinlikle güçlü) toplamda 20 maddeden oluşmaktadır. Ölçekte algısal motor beceriler ve güvenlik becerileri olarak tanımlanan iki alt boyut bulunmaktadır. Türkçe adaptasyonunda bir maddenin (koşullara göre hızı ayarlama) çapraz yüklenmesi nedeniyle algısal motor beceriler alt boyutu 13 maddeden, güvenlik becerileri alt boyutu ise 8 maddeden oluşmaktadır. Cronbach Alfa iç tutarlılık katsayıları sirasiyla .88 ve .76 olarak uygun düzeydedir.

\subsubsection{Araç simülatörü.}

Araştırmada STISIM DRIVE-M100W-ASPT sürüş simülasyon yazılımı, 22-inç LCD ekranlı DELL OptiPlex 980 bilgisayarında çalıştırılmıştır. Resim karesi hızı $60 \mathrm{~Hz}$ olarak belirlenmiş ve ekran çözünürlügü ise 1280x1024 olarak ayarlanmıştır. Deneye katılan sürücüler Logitech G27 yarış direksiyonu vasıtasıyla araçlarının pozisyonunu kontrol etmişlerdir.

Çalışmanın odağını şerit koruma performansında tutmak amacıyla sürücülere yalnızca direksiyon kontrolü verilmiştir. Sürücülerin görevin zorluk derecesindeki değişkenliklere göre hızlarını ayarlama ihtimali bulunduğundan, şerit tutma performansındaki hız kaynaklı değişiklerin önüne geçmek için gaz ve fren pedalları devre dışı bırakılmıştır. Aracın hızı 50 $\mathrm{ft} / \mathrm{sn}$. olarak sabitlenmiştir. Yirmi dakika süren sürüş simülasyonu 100 saniyelik 12 parçadan oluşmaktadır. On fit (3,05 m) genişliğindeki tek şeritli boş bir yolda ilerlenmiştir. Yol ve zemin rengi siyah olarak belirlenmiş ve beyaz kesik çizgilerle yolun sınırları çizilmiştir (bkz. Şekil 1). Aracın yoldan çıkmasıyla otomatik olarak yeniden ortada konumlanmasının önüne geçmek için tüm kazalar göz ardı edilmiştir. İkincil görevle etkileşime girmemesi açısından da sürüşe ait ses efektleri etkisiz kılınmıştır.

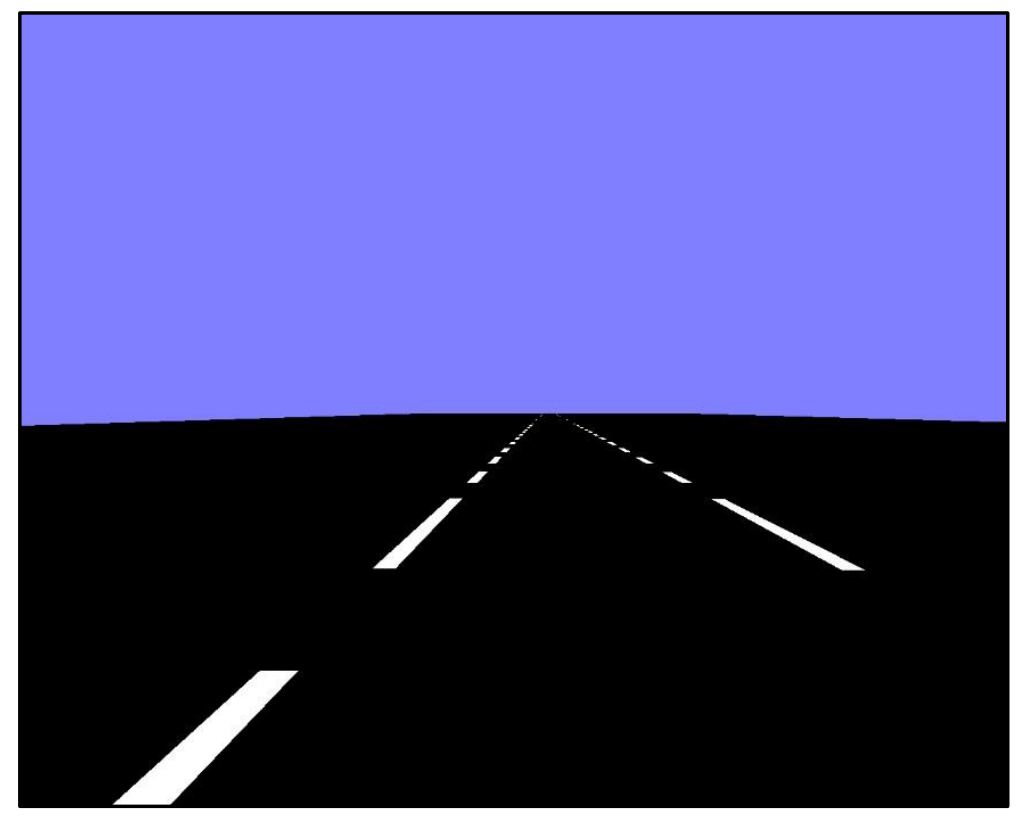

Şekil 1. Sürüş simülasyonu senaryosu

Deney senaryosu bir yüksek lisans tezi kapsamında tasarlanmıştır (Özbozdağlı, 2015). Bahsi geçen çalışmada, şerit koruma performansı ortama hafif ve güçlü rüzgâr eklenmesiyle ölçülmüştür. Güncel çalışmada ise farklı rüzgâr koşullarında kaydedilen şeritten sapma miktarlarının ortalaması alınarak performans ölçümü yapılmıştır. Tez çalışmasının amacı doğrultusunda, rüzgârın düzensizlik seviyesini belirleyen sinüzoidal parametre dosyaları senaryoya eklenmiştir. Tahmin edilebilir sürüş koşulu (düşük entropi) 10 tepe noktası bulunan tek sinüs dalgasından meydana gelmiştir. Tahmin edilemez sürüş koşulu (yüksek entropi) ise

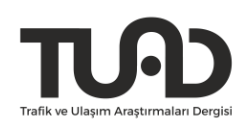


$2,5,10,25$ ve 50 tepe noktalı 5 sinüs dalgasından oluşmaktadır. Senaryoda rüzgârın olmaması halinde direksiyona dokunmadan şerit korunabileceği için bu koşul çalışmaya dâhil edilmemiştir. Bölüm başlangıçlarında araç yolun tam ortasında konumlandırılmıştır. Latin karesi tasarımıyla düzensizlik ve ikincil görevin sıralarının değiştiği 4 deney senaryosu oluşturulmuştur.

\subsection{4. İkincil görevler.}

\subsubsection{1. İşitsel 2-geri görevi.}

İşitsel ikincil görev olarak 2-geri görevi kullanılmıştır (Mehler ve ark., 2011). Katılımcılardan 2 rakam önce okunan rakamı yüksek sesle tekrarlamaları istenmiştir. Altı parçadan oluşan bu görevde, yönergeler ve uyarı sesleri hariç her parça 90 saniye sürmektedir. Her bölüm telefon çalma tonu (3 sn) ile başlayıp meşgul tonu (4 sn) ile bitmiştir. Sıfırdan dokuza kadar olan 30 uyarıcı rastgele şekilde dinletilmiştir. Uyarıcı süresi ve katılımcıya verilen cevap verme süresi 3 saniyedir (bkz. Şekil 2). İşitsel ikincil görev E-Prime 2.0 yazılımında hazırlanmış ve araç simülatörünün ekranının $10 \mathrm{~cm}$ sağ yanına konumlandırılan 8.9-inç ekran boyutlu küçük bir laptopta çalıştırılmıştır. Katılımcıların verdiği cevaplar Gigaware USB mikrofonlu kulaklık aracılığıyla kaydedilmiştir. Daha sonra, tüm katılımcılardan alınan ses kayıtları dinlenmiş ve yanıtlar doğru ya da yanlış olarak kodlanmıştır.

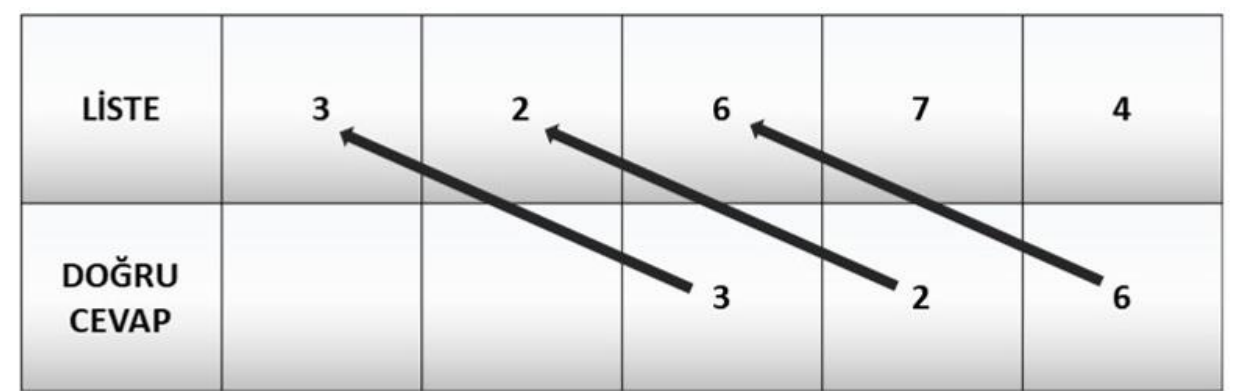

Şekil 2. İsitsel 2-geri görevi. Katılımcıdan 2 rakam önce okunan rakamı (0-9) yüksek sesle tekrarlaması istenmiştir. Her rakam için oluşturulan ses dosyası 1 sn sürmektedir. Uyarıcı süresi ve cevap verme süresi 3 sn olarak belirlenmiştir.

\subsubsection{Görsel 2-geri görevi.}

Görsel ikincil görev olarak art arda gelen bilginin bellekte sürekli takibini ve güncellenmesini gerektiren görsel 2-geri görevi tercih edilmiştir. Çoğunlukla sinirbilim alanında kullanılan bu görevin temelindeki fikir aynı kalsa da araştırma sorusuna bağlı olarak hedef obje, uyarıcı süresi ya da ekranda gösterilen konum sayısı gibi açılardan çalışmadan çalışmaya farklılıklar görülebilmektedir (Owen, McMillan, Laird ve Bullmore, 2005).

Mevcut çalışma için hazırlanan 2-geri görevinde, her biri 30 görselden oluşan 6 deney bölümü bulunmaktadır. Dört adet eşit parçaya bölünmüş bir karenin her defasında rastgele bir parçası griden siyaha dönüşmektedir ( $2 \mathrm{sn}$ ). Her uyarıcı arasında (1 sn) içi boş kare gösterilmiştir. İşitsel 2-geri görevinde olduğu gibi bu görevde de deney bölümleri telefon çalma sesi (3 sn) ile başlayıp meşgul tonu (4 sn) ile sona ermiştir. Sürücülerden siyah kare 2 görsel önceki kareyle aynı bölgeyse evet diyerek cevap vermeleri aksi durumda ise hayır demeleri istenmiştir (bkz. Şekil 3). Mikrofon aracılığıyla kaydedilen cevaplar daha sonra deney yürütücüsü tarafından doğru ve yanlış olarak kodlanmıştır. 


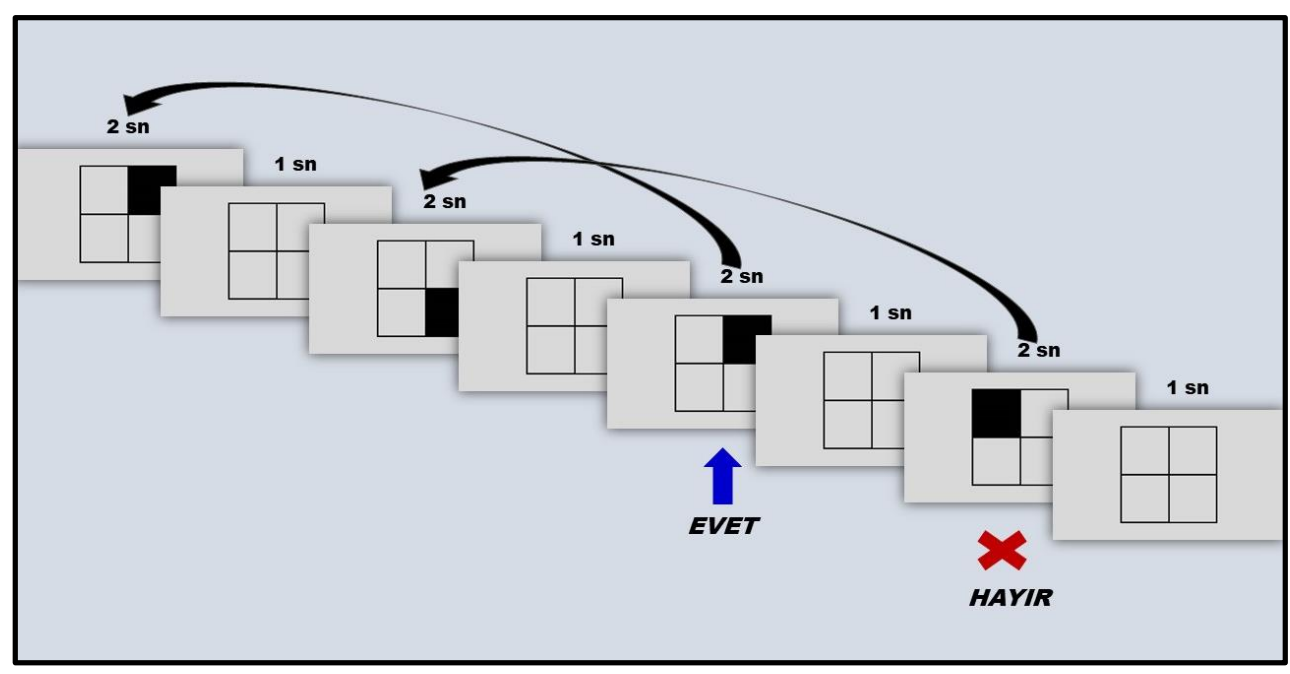

Şekil 3. Görsel 2-geri görevi. Katılımcıdan siyah kare 2 görsel önceki kareyle aynı bölgedeyse evet demesi, farklı bölgedeyse hayır demesi beklenmektedir. Her bir görsel uyarıcı 2 sn, uyarıcılar arasında sunulan içi boş kare ise 1 sn ekranda kalmıştır.

\section{3. İşlem}

Bilgilendirmiş onam formunun ve demografik bilgi formunun doldurulmasından sonra katılımcılar dâhil edildikleri deney grubuna göre işitsel ya da görsel ikincil görev alıştırması yapmışlardır. Bu kısımda, 2-geri görevlerin tam anlamıyla öğrenilmesi ve doğru şekilde icra edilmesi için katılımcılara verdikleri cevaplarla ilgili geri bildirim verilmiştir. Alıştırmaya peş peşe iki bölümde $\% 80$ doğruluğa ulaşılana dek devam edilmiştir. Bilgisayarda 2-geri görevinin 90 saniyelik pratiği yapılmasının akabinde 100 saniye süren sürüş simülasyonu tamamlanmıştır. Son olarak 100 saniyelik bir alıştırma ile sürüş ve ikincil görev bir arada yapılmıştır. Ana deney 20 dakika olmak üzere her oturum yaklaşık 40 dakika sürmüştür. Deneye katılan sürücülerden rüzgâra rağmen yolun ortasından ilerlemeleri istenmiştir. Yüz saniyelik 6 bölümde yalnızca araç kullanan katılımcılar, 100 saniyelik diğer 6 bölümde de direksiyon başındayken ikincil görevi yapmışlardır. Bu bölümlerin yarısı tahmin edilebilir diğer yarısı tahmin edilemez çapraz rüzgârlar içermektedir.

\section{Bulgular}

Çalışmada kullanılan simülatör çıktı olarak aracın yolun tam ortasına göre konumunu fit değerinden vermiştir. Veri setinde yolun ortası sıfır alınmış, lateral konum araç yolun sağ tarafında ise pozitif, sol tarafında ise negatif sayılar ile belirtilmiştir. Pozitif ve negatif sayıların birbirini götürmemesi için şerit pozisyonundaki değişkenlik bu değerlerin ortalama karekökleri alınarak her bir katılımcı için hesaplanmıştır. Daha sonra ikincil görevin olduğu ve olmadığı koşullar için ortalamaları alınmıştır.

Deney verilerinin analizi SPSS programı ile yapılmıştır. Anlamlılık düzeyi $\mathrm{p}<0.05 \mathrm{kabul}$ edilmiştir. Çoklu doğrusal regresyon analizleri yapılarak algısal motor beceriler ve güvenlik becerileri alt boyutlarının işitsel ve görsel ikincil görevler ile meşgulken ya da sadece sürüş ile ilgilenildiğinde sergilenen şerit pozisyonundaki değişkenliğini yordama güçleri incelenmiştir. İşitsel ikincil görev koşulu için yapılan analizde regresyon modelinin istatistiksel açıdan anlamlı olmadığı bulunmuştur, $F(2,30)=2.53, p=.1, R^{2}=.15$. Sürücülük Becerisi Ölçeğinin iki alt boyutunun da sürücülerin şeritten sapma davranışlarını yordamadaki katkıları anlamlı değildir.

İşitsel ikincil görev grubundaki sürücülerin sadece sürüş ile ilgilendiklerinde sergiledikleri şeritten sapma miktarını yordamada algısal motor becerilerin ve güvenlik becerilerinin katkısını

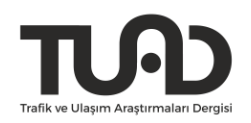


görmek amacıyla yapılan analizde regresyon denkleminin istatistiksel olarak anlamlı olduğu bulunmuştur, $F(2,30)=3.59, p=.04, R^{2}=.19$. Algisal motor beceriler şerit pozisyonundaki değişkenlik ile negatif yönde ilişkiliyken $(\beta=-.43, t(30)=-2.57, p=.01)$, güvenlik becerileri ile şerit pozisyonundaki değişkenlik arasında anlamlı bir ilişki bulunmadığı görülmektedir (bkz. Tablo 1).

Tablo 1. Sürücülük Becerisinin İşitsel İkincil Görev Grubunda Gözlemlenen Şerit Pozisyonundaki Değģskenlik ile Olan İlişkisine ilişskin Çoklu Doğrusal Regresyon Analizi Bulgulart

\begin{tabular}{|c|c|c|c|c|c|c|c|}
\hline \multirow[b]{2}{*}{ Deney Koşulu } & \multirow[b]{2}{*}{ Yordayıcı Değişkenler } & \multicolumn{4}{|c|}{ Model } & \multirow[b]{2}{*}{$B$} & \multirow[b]{2}{*}{$p$} \\
\hline & & $R$ & $R^{2}$ & $\begin{array}{c}\text { Standart } \\
\text { Hata }\end{array}$ & $F$ & & \\
\hline \multirow{2}{*}{$\begin{array}{l}\text { İşitsel İkincil } \\
\text { Görev }\end{array}$} & Algisal Motor Beceriler & \multirow{2}{*}{.38} & \multirow{2}{*}{.15} & \multirow{2}{*}{.61} & \multirow{2}{*}{2.53} & -.30 & .09 \\
\hline & Güvenlik Becerileri & & & & & .17 & .33 \\
\hline \multirow{2}{*}{ Sadece Sürüş } & Algisal Motor Beceriler & \multirow{2}{*}{.44} & \multirow{2}{*}{.19} & \multirow{2}{*}{.53} & \multirow{2}{*}{3.59} & $-.43^{*}$ & .01 \\
\hline & Güvenlik Becerileri & & & & & .03 & .88 \\
\hline
\end{tabular}

$* p<.05 ; * * p<.01$

Algısal motor beceriler ve güvenlik becerilerinin, görsel ikincil görev koşulunda, şerit pozisyonu değişkenliğini yordamadaki paylarını incelemek için yapılan analizde regresyon denkleminin anlamlı olduğu bulunmuştur, $F(2,30)=9.34, p=.001, R^{2}=.38$. Görsel görev ile meşgul olunduğunda gözlemlenen şerit pozisyonundaki değişkenliğin güvenlik becerileri ile anlamlı olarak ilişkili olmadığı görülmüştür. Öte yandan, algısal motor beceriler ile orta şeritten sapma arasında negatif yönde anlamlı bir ilişki bulunmuştur, $\beta=-.60, t(30)=-4.12, p<.001$.

Görsel ikincil görev grubundaki sürücülerin yalnızca sürüş ile meşgul olduklarında sergiledikleri şeritten sapma miktarını yordamada algısal motor becerilerin ve güvenlik becerilerinin katkılarını görmek amacıyla uygulanan analizde ise regresyon denkleminin istatistiksel olarak anlamlı olduğu görülmüştür, $F(2,30)=12.37, p<.001, R^{2}=.45$. Algisal motor beceriler ile şeritten sapma negatif yönde ilişkiliyken $(\beta=-.66, t(30)=-4.85, p<.001)$, güvenlik becerileri ile şerit pozisyonundaki değişkenlik arasında anlamlı bir ilişki bulunmamıştır (bkz. Tablo 2).

Tablo 2. Sürücülük Becerisinin Görsel İkincil Görev Grubunda Gözlemlenen Şerit Pozisyonundaki Değiş̧enlik ile Olan Illişkisine ilişkin Çoklu Doğrusal Regresyon Analizi Bulgulart

\begin{tabular}{|c|c|c|c|c|c|c|c|}
\hline \multirow[b]{2}{*}{ Deney Koşulu } & \multirow[b]{2}{*}{ Yordayıcı Değişkenler } & \multicolumn{4}{|c|}{ Model } & \multirow[b]{2}{*}{$\beta$} & \multirow[b]{2}{*}{$p$} \\
\hline & & $R$ & $R^{2}$ & $\begin{array}{c}\text { Standart } \\
\text { Hata }\end{array}$ & $F$ & & \\
\hline $\begin{array}{l}\text { Görsel İkincil } \\
\text { Görev }\end{array}$ & $\begin{array}{c}\text { Algısal Motor Beceriler } \\
\text { Güvenlik Becerileri }\end{array}$ & .62 & .38 & .49 & 9.34 & $\begin{array}{l}-.60 * * \\
.10\end{array}$ & $\begin{array}{l}.000 \\
.51\end{array}$ \\
\hline Sadece Sürüş & $\begin{array}{l}\text { Algisal Motor Beceriler } \\
\text { Güvenlik Becerileri }\end{array}$ & .67 & .45 & .28 & 12.37 & $\begin{array}{l}-.66 * * \\
.05\end{array}$ & $\begin{array}{l}.000 \\
.70\end{array}$ \\
\hline
\end{tabular}

$* p<.05 ; * * p<.01$ 


\section{Tartışma}

Bu çalışmada, sürücülük becerisi ölçeğinin algısal motor beceriler ve güvenlik becerileri alt boyutlarının, direksiyon başında işitsel ve görsel ikincil görevler yapıldığı sırada ya da sadece sürüş ile ilgilenildiğinde sergilenen şerit pozisyonundaki değişkenliği yordama güçleri araştırılmıştır. Elde edilen bulgulara göre, ikincil görev işitsel olduğunda, ölçeğin iki alt boyutunun da şeritten sapma miktarını yordamadaki katkılarının anlamlı olmadığı görülmüştür. Buna karşın, aynı gruptaki katılımcılar sadece ana görevleri olan sürüş ile uğraştıklarında, algısal motor becerilerin şerit pozisyonundaki değişkenlik ile negatif yönde ilişkili olduğu bulunmuştur.

Şerit koruma performansı ile algısal motor beceriler arasında sadece sürüş koşulunda anlamlı bir ilişki görülürken, sürüşe ek olarak işitsel bir görevle ilgilenildiğinde anlamlı bir ilişkinin saptanamaması araştırmaya katılan sürücülerin deneyimli olmalarından kaynaklanıyor olabilir. Bir görevde yeterince tecrübe sahibi olan kişilerin ana göreve odaklanmadıklarında performanslarının iyileştiği, odaklandıklarında ise performanslarının düştüğü önceki çalışmalarda gösterilmiştir. Örneğin, daktiloda yazı yazmada uzman kişilerde her bir tuş vuruşuna odaklanmaları istendiğinde performanslarında düşüş gerçekleşmiştir (Logan ve Crump, 2009; Tapp ve Logan, 2011). Benzer şekilde, katılımcıların tecrübeli sürücülerden oluştuğu bir çalışmada işitsel ikincil görev yapılırken şerit pozisyonundaki değişkenliğin azaldığ 1 bulunmuştur (Medeiros-Ward ve ark., 2014). Engström ve ark. (2005) ise işitsel görev esnasında şeritten sapma miktarının azalmasını sürücünün dikkatini yolun merkezine vermesine ve dolaylı olarak şerit koruma için daha çok girdi alınmış olmasına dayandırmıştır. Tüm bu bulgu ve varsayımlar dikkate alındığında, işitsel görev süresince iyileşme gösteren şerit koruma performansı, algısal motor beceriler ve şerit pozisyonundaki değişkenlik arasındaki anlamlı ilişki görülmemesinin arkasında yatan nedenlerden biri olabileceği düşünülmektedir. Algısal motor becerilerine güvenen deneyimli sürücüler, sadece aracı kullanmaya odaklandıklarında şeritten ne ölçüde sapacaklarına dair doğru bir yargıya sahip olabilirler. Öte yandan, bu güven, direksiyon başındayken işitsel bir görev yapıldığında, otomatik hale gelmiş olan şerit koruma performansının artmasını kapsamayabilir. Sürücülerin becerilerine olan güvenlerini belirleyen geçmiş deneyimlerinde bu otomatikleşmiş süreç farkındalık seviyesine ulaşmamış olabilir. Ek olarak, kullanılan ölçekte algısal motor becerileri temsil eden maddeler genel sürücülük becerilerini içermektedir. Katılımcılar, değerlendirmelerini ikincil görevle meşgul oldukları anları da hesaba katarak yapmamış olabilirler.

İkincil görevin görsel olduğu koşulda ise algısal motor beceriler ile şerit pozisyonundaki değişkenlik arasında negatif yönde bir ilişki bulunmuştur. Bilişsel bir yük oluşturan ikincil görevin şerit koruma üzerindeki olumlu etkisi görsel görev esnasında gözlerin yoldan ayrılmasıyla bertaraf edilmiş olabilir. Şeritten sapma miktarının direksiyon başında görsel görevle ilgilenildiğinde arttığının, işitsel görevle ilgilenildiğinde ise azaldığının Engström ve ark. (2005) tarafından yapılan çalışmada gösterilmesi bu varsayımı desteklemektedir. Katılımcıların sadece sürüş ile meşgul olduğu durumda da algısal motor beceriler ile şeritten sapma miktarı arasında negatif bir ilişki saptanmıştır. Elde edilen bulgular, görsel bir görevin sürüşe eşlik etmesinden bağımsız olarak algısal motor beceriler alt boyutunun şerit pozisyonunu korumayı yordama gücüne sahip olduğu şeklinde yorumlanabilir.

Son olarak, hiçbir koşulda, güvenlik becerileri ile şerit pozisyonundaki değişkenlik arasında anlamlı bir ilişki tespit edilememiştir. Genellikle psikoteknik değerlendirmeyle ölçülmeye çalışılan algısal motor beceriler, sürüş için gerekli olan fiziksel ve bilişsel özellikleri içermektedir (Lajunen ve Summala, 1995). Sürücülerin güvenlik anlayışlarından ziyade şerit pozisyonundaki değişkenliğin, algısal motor beceriler tanımının kapsamına girdiği düşünülebilir. Mevcut çalışmada ise kullanılan sade sürüş senaryosu güvenlik becerilerini

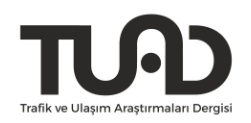


ölçmede yetersiz kalmış olabilir, zira araç kullanma farklı seviyelerdeki pek çok görevin birleşiminden oluşmaktadır.

Michon (1985) araç kullanmayı 3 kontrol kademesine ayırarak ele almıştır (Oppenheim ve Shinar, 2011). En temel seviye olan, operasyonel seviye otomatikleşmiş davranışları ve değişen trafiğe anbean verilen tepkileri içermektedir. Şerit pozisyonunu korumak da operasyonel seviyeye ait bir davranıştır. İkinci seviye ise taktiksel kontroldür ve kısa vadeli hedefleri, bilinçli sürüş kararlarını içermektedir. Öndeki aracı sollamak, yoldaki engellerden sakınmak, dönüşten önce şerit değiştirmek bu davranışlar arasında yer almaktadır. Çalışmada kullanılan sürüş senaryosunda ise araç, düz ve trafiksiz bir yolda ilerlemektedir. Son ve en üst düzey kontrolü yansıtan seviye rotaya karar vermek, trafik olmayan yolları tercih etmek gibi stratejik kararları içermektedir (Michon, 1985). Güvenlik becerileri, otomatikleşen araç kontrol hamlelerinden ziyade bilinçli kararları kapsayan taktiksel ve stratejik seviyelere ait davranışları yordayabilir. Gelecekteki çalışmalarda taktiksel ve stratejik görevlerin de eklendiği daha zengin bir senaryo kullanılarak bu olasılık test edilebilir.

Mevcut çalışmada, algısal motor beceriler alt boyutunun şerit koruma performansını yordamada daha güçlü olduğu, güvenlik beceriler alt boyutunun ise hiçbir deney koşulunda sergilenen şerit pozisyonundaki değişkenlik ile anlamlı bir ilişki göstermediği bulunmuştur. Direksiyon başındayken sürücünün meşgul olduğu ikincil görevin türünün de algısal motor becerilerin şerit koruma davranışını yordamada önemli bir rolü olduğu gösterilmiştir. Gelecek araştırmalar bu çalışmada keşfedilen bulgular göz önüne alınarak tasarlanabilir.

\section{Yazar Notları:}

Mevcut çalışmada kullanılan veriler birinci yazarın yüksek lisans tezi kapsamında toplanmıştır (Özbozdağl1, 2015). Tez kapsamında elde edilen verilen bir bölümü kullanılarak ikincil görevin otomatik ve kontrollü şerit içinde kalma davranışı üzerindeki etkisi incelenmiş ve elde edilen bulgular Özbozdağl1, Misirlisoy, Özkan ve Atalay (2018)'de rapor edilmiştir. Bu makalede ise ilgili tezin kapsamına ek olarak Sürücülük Becerisi Ölçeği (Lajunen ve Özkan, 2004) ile ölçülen algısal motor beceriler ile güvenlik becerilerindeki bireysel farklılıkların ikincil görev altındaki şerit koruma performansını yordayıp yordamadığı analiz edilmiştir. 


\section{Kaynakça}

Beede, K. E. ve Kass, S. J. (2006). Engrossed in conversation: The impact of cell phones on simulated driving performance. Accident Analysis and Prevention, 38, 415-421. doi:10.1016/j.aap.2005.10.015

Caird, J. K., Willness, C. R., Steel, P. ve Scialfa, C. (2008). A meta-analysis of the effects of cell phones on driver performance. Accident Analysis \& Prevention, 40(4), 1282-1293. doi:10.1016/j.aap.2008.01.009

Drews, F. A., Pasupathi, M. ve Strayer, D. L. (2008). Passenger and cell phone conversations in simulated driving. Journal of Experimental Psychology: Applied, 14(4), 392-400. doi:10.1037/a0013119

Eensoo, D., Paaver, M. ve Harro, J. (2010). Factors Associated with Speeding Penalties in Novice Drivers. Annals of advances in automotive medicine. Association for the Advancement of Automotive Medicine. Annual Scientific Conference, 54, 287-294.

Engström, J., Johansson, E. ve Östlund, J. (2005). Effects of visual and cognitive load in real and simulated motorway driving. Transportation Research Part F: Traffic Psychology and Behaviour, 8, 97-120. doi:10.1016/j.trf.2005.04.012

Haque, M. M. ve Washington, S. (2014). A parametric duration model of the reaction times of drivers distracted by mobile phone conversations. Accident Analysis and Prevention, 62, 42-53. doi:10.1016/j.aap.2013.09.010

He, J., Choi, W., McCarley, J. S., Chaparro, B. S. ve Wang, C. (2015). Texting while driving using Google Glass: Promising but not distraction-free. Accident Analysis and Prevention, 81, 218-229. doi:10.1016/j.aap.2015.03.033

Jamson, A. H. ve Merat, N. (2005). Surrogate in-vehicle information systems and driver behaviour: Effects of visual and cognitive load in simulated rural driving. Transportation Research Part F: Traffic Psychology and Behaviour, 8, 79-96. doi:10.1016/j.trf.2005.04.002

Kircher, K. ve Ahlstrom, C. (2017). Minimum required attention: A human-centered approach to driver inattention. Human Factors, 59(3), 471-484. doi:10.1177/0018720816672756

Kubose, T. T., Bock, K., Dell, G. S., Garnsey, S. M., Kramer, A. F. ve Mayhugh, J. (2006). The effects of speech production and speech comprehension on simulated driving performance. Applied Cognitive Psychology, 20(1), 43-63. doi: 10.1002/acp.1164

Lajunen, T., Corry, A., Summala, H. ve Hartley, L. (1998). Cross-cultural differences in drivers' self-assessments of their perceptual-motor and safety skills: Australians and Finns. Personality and Individual Differences, 24(4), 539-550.

Lajunen, T. ve Özkan, T. (2004). Kültür, güvenlik kültürü, Türkiye ve Avrupa'da trafik güvenliği. Tübitak.

Lajunen, T., Parker, D. ve Stradling, S. G. (1998). Dimensions of driver anger, aggressive and highway code violations and their mediation by safety orientation in UK drivers. Transportation Research Part F: Traffic Psychology and Behaviour, 1(2), 107-121. doi:10.1016/s1369-8478(98)00009-6 
Lajunen, T. ve Summala, H. (1995). Driving experience, personality, and skill and safetymotive dimensions in drivers' self-assessments. Personality \& Individual Differences, 19(3), 307-318

Liang, Y. ve Lee, J. D. (2010). Combining cognitive and visual distraction: Less than the sum of its parts. Accident Analysis and Prevention, 42, 881-890. doi: 10.1016/j.aap.2009.05.001

Logan, G. D. ve Crump, M. J. (2009). The left hand doesn't know what the right hand is doing. Psychological Science, 20(10), 1296-1300.

Medeiros-Ward, N., Cooper, J. M. ve Strayer, D. L. (2014). Hierarchical control and driving. Journal of Experimental Psychology: General, 143(3), 953-958. doi: $10.1037 / \mathrm{a} 0035097$

Mehler, B., Reimer, B. ve Dusek, J. A. (2011). MIT AgeLab delayed digit recall cask (n-back) [White paper]. http://dosen.narotama.ac.id/wp-content/uploads/2012/03/MIT-AgeLabdelayed-digit-recall-task-n-back.pdf

Metz, B., Schoch, S., Just, M. ve Kuhn, F. (2014). How do drivers interact with navigation systems in real life conditions? Results of a field-operational-test on navigation systems. Transportation Research Part F: Traffic Psychology and Behaviour, 24, 146-157. doi:10.1016/j.trf.2014.04.011

Michon, J. A. (1985). A critical view of driver behavior models: What do we know, what should we do? Human Behavior and Traffic Safety, 485-524. doi:10.1007/978-1-4613-21736_19

National Center for Statistics and Analysis. (2017, Mart). Distracted driving 2015. (Traffic Safety Facts Research Note. Report No. DOT HS 812 381). Washington, DC: National Highway Traffic Safety Administration.

Oppenheim, L. ve Shinar, D. (2011). Human factors and ergonomics. B. E. Porter (Ed.), Handbook of traffic psychology içinde (s.193-211). Londra: Academic Press.

Owen, A. M., McMillan, K. M., Laird, A. R. ve Bullmore, E. (2005). N-back working memory paradigm: A meta-analysis of normative functional neuroimaging studies. Human Brain Mapping, 25(1), 46-59. doi:10.1002/hbm.20131

Özbozdağlı, S. (2015). The effects of auditory and visuo-spatial secondary tasks on lane maintenance in predictable and unpredictable driving conditions. (Yayımlanmamış yüksek lisans tezi). Orta Doğu Teknik Üniversitesi, Ankara.

Özbozdağlı, S., Misirlisoy, M., Özkan, T. ve Atalay, N. B. (2018). Effects of primary task predictability and secondary task modality on lane maintenance. Transportation Research Part F: Traffic Psychology and Behaviour, 57, 97-107. doi:10.1016/j.trf.2017.10.005

Parkes, A. M. ve Coleman, N. (1990). Route guidance systems: A comparison of methods of presenting directional information to the driver. E. J. Lovesey (Ed.), Contemporary ergonomics 1990 içinde (s. 480-485). Londra: Taylor \& Francis.

Schömig, N., Metz, B. ve Krüger, H. P. (2011). Anticipatory and control processes in the interaction with secondary tasks while driving. Transportation Research Part F: Traffic Psychology and Behaviour, 14, 525-538. doi: 10.1016/j.trf.2011.06.006

\section{TQD}


Schroeder, P., Meyers, M. ve Kostyniuk, L. (2013, Nisan). National survey on distracted driving attitudes and behaviors - 2012. (Report No. DOT HS 811 729). Washington, DC: National Highway Traffic Safety Administration

Strayer, D. L. ve Drews, F. A. (2004). Profiles in driver distraction: Effects of cell phone conversations on younger and older drivers. Human Factors, 46(4), 640-649.

Strayer, D. L., Drews, F. A. ve Crouch, D. J. (2006). A comparison of the cell phone driver and the drunk driver. Human Factors, 48(2), 381-391.

Sümer, N., Lajunen, T. ve Özkan, T. (2002). Sürücü davranışlarının kaza riskindeki rolleri: İhlaller ve hatalar. Uluslararası Trafik ve Yol Güvenliği Kongresi ve Fuarı. 8-12 Mayıs, 2002, Gazi Üniversitesi, Ankara.

Sümer, N., Özkan, T. ve Lajunen, T. (2006). Asymmetric relationship between driving and safety skills. Accident Analysis and Prevention, 38, 703-711.

Tapp, K. M. ve Logan, G. D. (2011). Attention to the hands disrupts skilled typewriting: The role of vision in producing the disruption. Attention, Perception, \& Psychophysics, 73, 2379-2383.

Thapa, R., Codjoe, J., Ishak, S. ve McCarter, K. S. (2015). Post and during event effect of cell phone talking and texting on driving performance: A driving simulator study. Traffic Injury Prevention, 16, 461-467. doi: 10.1080/15389588.2014.969803

Treisman, A. ve Davies, A. (1973). Divided attention to ear and eye. S. Kornblum (Ed.) Attention and performance IV içinde (s. 101-117). New York, NY: Academic Press.

Türkiye İstatistik Kurumu (2017). Karayolu Trafik Kaza Istatistikleri, 2016. Ankara, Türkiye. Erişim Tarihi: 03.04.2018, http://www.tuik.gov.tr/PreHaberBultenleri.do?id=24606 